\title{
ROBIN COOKE, HUMAN RIGHTS AND THE PACIFIC DIMENSION
}

\author{
Hon Justice Michael Kirby AC CMG*
}

Lord Cooke's life as lawyer and judge was astonishing in its achievements. The author traces his counter-cultural embrace of notions of human rights both in case decisions and in scholarly articles. He describes Lord Cooke's approach to judging - a mixture of orthodoxy and radical new ideas. He describes his contribution to the emergence of a distinctive New Zealand jurisprudence, curiously asserted in advance of the termination of Privy Council appeals and before similar "liberation" in Australia. The author concludes with a reminder of Lord Cooke's prediction of a "common law of the world". He suggests that building an effective regional human rights mechanism for the Pacific would be a timely and practical contribution to that ideal.

\section{LUMINARY AND FRIEND}

Robin Brunskill Cooke was an outstanding jurist. He was my friend. It has been said that he was one of the finest judges that New Zealand has produced. ${ }^{1}$ He was the first judge from New Zealand to be made a life peer. ${ }^{2} \mathrm{He}$ was also the first Commonwealth judge to participate in the Appellate

* Justice of the High Court of Australia. I acknowledge the assistance of Mr Adam Sharpe, legal research officer in the Library of the High Court of Australia.

1 Sir Michael Hardie Boys, when Governor-General, described Cooke as "undoubtedly one of New Zealand's intellectual giants" and "arguably [New Zealand's] greatest Judge". See the speech, given at the opening of the Legal Research Foundation Conference, Auckland, 4 and 5 April 1997, reproduced in Paul Rishworth (ed) The Struggle for Simplicity in the Law: Essays for Lord Cooke of Thorndon (Butterworths, New Zealand, 1997) 331, 336. Sir Geoffrey Palmer, past Prime Minister and now President of the New Zealand Law Commission went further, asserting that "it must [be] recognised that Lord Cooke is the greatest [j]udge that New Zealand has produced": see McGuire v Hastings District Council [2002] 2 NZLR 577, 584 (PC).

2 Peter Spiller New Zealand Court of Appeal 1958-1996: A History (Brookers, Wellington, 2002) 121. He became Baron Cooke of Thorndon of Wellington in New Zealand, and of Cambridge in the County of Cambridgeshire. 
Committee of the House of Lords deciding United Kingdom appeals. ${ }^{3}$ This says a lot about him. It also says much about the United Kingdom.

His remarkable life's journey has been recounted many times. ${ }^{4}$ This contribution aims to provide some reflections upon his legacy. That is no easy task, for he has influenced the jurisprudence not only of New Zealand but of the wider common law world. His contribution to law extends across the horizon of many legal subjects. ${ }^{5}$ In my essay, I shall refer to him as Cooke. In his lifetime, I was privileged to call him by his given name; but that appellation would be too familiar for a work of this kind. He wore all of his titles - Mr, Justice, Sir, Lord and Baron - with equal grace. For him what mattered most were ideas. He would not object to the simplicity of Cooke.

I aim to isolate a few aspects of his legacy. I will examine his contribution to understandings of human rights and the role of the judge. I will explore his part in the development of a distinctive New Zealand jurisprudence. I will then consider the prospects for a Pacific Charter of Rights as a rational outcome, beyond New Zealand and Australia, of the kind of causes that Cooke espoused as a judge and as a citizen.

Without delay, I hope that a biographer worthy of the task will provide a detailed description and analysis of Cooke's life and legacy. In the meantime, I applaud the initiative of the Victoria University of Wellington to compile a special issue of this journal to commemorate Cooke. He was, of course, richly decorated with the outward trappings of ermine and medallions of gold and enamel. Now that his physical presence is no more, we are left with the still vivid recollections of his personality and the treasury of his writings revealing the workings of the mind of a modern man concerned to better the condition of the law and the human condition within society.

\section{HUMAN RIGHTS}

A great teacher: During a discussion about human rights, in an $\mathrm{ABC}$ radio interview which Cooke and I shared in 2000, I referred to him as "one of the great teachers in this area [of the

3 Peter Spiller "Lord Cooke of Thorndon: The New Zealand Dimension" (2002) 10 Waikato LR 55, 61.

4 See for example Nilay B Patel "Lord Cooke of Thorndon (1926-2006): 51 Years in the Law" (2006) 32 CLB 443; Peter Spiller "Lord Cooke of Thorndon: an appreciation" [2006] NZLJ 321; Sian Elias "Eulogy for Lord Cooke of Thorndon" [2006] NZLJ 323 and in this issue, and my own tribute: (2006) 80 ALJ 868.

5 Chief Justice Elias has observed that "There is no area of law that his judgments do not touch." See Elias, above n 4, 324. Mr Geoff McLay has written that "Lord Cooke inhabited the subjects that I studied and that I teach. It was simply impossible to make sense of New Zealand law in diverse areas like tort, contract, constitutional law, equity or trusts without directly confronting Lord Cooke's view of the law as a whole." See Geoff McLay "Sir Robin Cooke" (2006) 37 VUWLR 335, 336. 
law]". ${ }^{6}$ Chief Justice Sian Elias has also referred to his "deep commitment to human rights". ${ }^{7}$ His passion for, and contribution to, human rights jurisprudence in Australasia, and across the common law world, were enormous. They provide the starting point for this reflection.

A rights-based approach: Cooke argued that a fundamental shift had come upon the rule of law in the common law world in recent decades. He saw a movement in our law from a somewhat negative or passive view about the rule of law to a more active one, affirmatively defensive of human rights: ${ }^{8}$

The Diceyan concept of the rule of law was that citizens may do what they like unless the State has sufficiently express powers of intervention. [This] is steadily being replaced by more positive thinking in terms of the identifiable rights of human beings which States are bound to respect and further.

In the New Zealand context, Cooke's understanding of the effect of the adoption of the New Zealand Bill of Rights Act 1990 certainly suggests that his prediction was true so far as the direction of New Zealand law was concerned. He argued that the Bill of Rights had come to permeate both statute law and the common law in New Zealand, and further that: ${ }^{9}$

[The Bill of Rights] cannot rightly be seen as some special and somewhat arcane or foreign phenomenon standing apart from the day-to-day practice and administration of the law. We are slowly but surely learning this approach in New Zealand. ... In the language being adopted in the Bloemfontein Statement, "in democratic societies fundamental human rights and freedoms are more than paper aspirations. They form part of the law".

Legal remedies for rights: Cooke believed in the importance of integrating human rights principles into law. He also believed in the practical implementation of such rights. This belief is perhaps nowhere more clearly demonstrated than in his decision in Simpson v Attorney-General (Baigent's case), ${ }^{10}$ the effect of which was explained by Cooke in the following terms: ${ }^{11}$

6 ABC Radio National "Politics and the Courts" (29 August 2000) The Law Report available at www.abc.net.au (accessed 23 March 2007).

7 Elias "Eulogy", above n 4, 325.

8 Robin B Cooke "Human Rights in Hong Kong" (1999) 29 VUWLR 45, 45 (emphasis in original).

9 Robin B Cooke "A Sketch from the Blue Train - Non-discrimination and freedom of expression: The New Zealand Contribution" [1994] NZLJ 10, 12.

10 Simpson v Attorney-General (Baigent's case) [1994] 3 NZLR 667 (CA).

11 Cooke "Human Rights in Hong Kong", above n 8, 47. Compare my reasons in APLA Ltd v Legal Services Commissioner (NSW) (2005) 224 CLR 322, 412 para 255 and 428-429 paras 312-313. 
The essence of Baigent is that the enactment of a legal right is meaningless and window-dressing without a legal remedy; the appropriate remedy is the one most effective in the circumstances; it is the duty of the courts to provide legal remedies for the breach of legal rights.

Cooke observed that Baigent was "the [decision] most selected for attack by some academic lawyers and others in New Zealand itself". He responded: ${ }^{12}$

The more influential the anti-Baigent school of thought in [New Zealand], the more out of touch we will be with the trend towards internationally-recognised human rights which is so noticeable throughout the world.

International and domestic law: Cooke was thus in the vanguard in propounding the belief that international human rights norms were to be implemented in domestic law wherever it was appropriate that this should occur. In 1977, in Van Gorkon v Attorney-General, ${ }^{13}$ Cooke took into account the Universal Declaration of Human Rights and the Declaration on the Elimination of Discrimination against Women in deciding that conditions imposed by the Minister of Education for the payment of teachers' removal expenses which discriminated on the basis of the teachers' sex were invalid. ${ }^{14}$ In her eulogy in Wellington, Chief Justice Sian Elias said of this decision that "[i]t was a leap we in New Zealand now take for granted but which was breathtaking then." 15

Cooke's decision in that case was to prove prescient. It preceded by more than ten years the Bangalore Principles which were adopted in Bangalore, India in February $1988 .{ }^{16}$ Very often, Cooke was a judge ahead of his time.

In Tavita $v$ Minister of Immigration, ${ }^{17}$ the New Zealand Court of Appeal considered the effect upon domestic law of an international treaty which had been ratified by the executive but not expressly implemented as part of domestic law by parliamentary legislation. A removal warrant had been executed on Mr Tavita after he had overstayed his visa. When the New Zealand Immigration Service took steps to remove him from the country, Mr Tavita sought relief by way of judicial review. His case reached the New Zealand Court of Appeal. By the time of the decision, Mr Tavita

12 Cooke "Human Rights in Hong Kong", above n 8, 47.

13 Van Gorkon v Attorney-General [1977] 1 NZLR 535 (SC).

14 Ibid, 542-543 Cooke J. Contrast New South Wales v Amery (2006) 80 ALJR 753 (HCA).

15 Elias "Eulogy", above n 4, 325.

16 For discussion of the Bangalore Principles, see for example my article "Domestic Implementation of International Human Rights Norms" (1999) 5 AJHR 109, especially 115-116.

17 Tavita v Minister of Immigration [1994] 2 NZLR 257. 
had married and a daughter had been born in New Zealand. She was a New Zealand citizen. If expulsion were upheld, Mr Tavita would be separated from his wife and daughter.

As President of the New Zealand Court of Appeal, Cooke, on behalf of the Court, delivered an interim decision. He identified the argument of the executive as being that the International Covenant on Civil and Political Rights 1966 and the United Nations Convention on the Rights of the Child 1989 ("UNCROC") did not have to be considered at all in determining whether to order $\mathrm{Mr}$ Tavita's removal. Although not making a final decision on that argument, Cooke commented: ${ }^{18}$

That is an unattractive argument, apparently implying that New Zealand's adherence to the international instruments has been at least partly window-dressing.

The case was ultimately resolved without further recourse to the courts, when the Minister of Immigration permitted Mr Tavita to remain in New Zealand. ${ }^{19}$ However, an important blow had been struck and it was to be repeated.

Tavita's legacy: Tavita demonstrates the international impact of Cooke's decision-making. The decision in Tavita predates, and seems likely to have influenced, the decision of the High Court of Australia in Minister of State for Immigration and Ethnic Affairs $v$ Teoh. ${ }^{20}$ In Teoh, the High Court held that $\mathrm{Mr}$ Teoh, also an applicant for a visa, had a legitimate expectation that the Australian Minister for Immigration would act in accordance with UNCROC, which Australia too had ratified but not yet implemented by statute in domestic law. ${ }^{21}$

In Baker $v$ Minister of Citizenship and Immigration, ${ }^{22}$ the Supreme Court of Canada was presented with similar factual circumstances. In that case, the executive had ordered that the appellant be deported for overstaying her visitor's visa and working in Canada illegally. The appellant had given birth to no fewer than four Canadian-born children by the time of the order. The appellant sought to be exempted from the requirement of applying for permanent residence outside Canada. She did so by seeking the exercise of the power to admit a person to Canada on the basis of

18 Ibid, 266 Cooke P.

19 See Robin B Cooke "The Dream of an International Common Law" in Cheryl Saunders (ed) Courts of Final Jurisdiction: The Mason Court in Australia (The Federation Press, Annandale (NSW), 1996) 144.

20 Minister of State for Immigration and Ethnic Affairs v Teoh (1995) 183 CLR 273. See, for example, the reasons of Toohey $\mathrm{J}$ at page 300 , in which he quotes Tavita.

21 Although some cold water has been thrown on the authority of Teoh, it has not been expressly overruled: see Michael D Kirby "Chief Justice Nicholson, Australian Family Law and International Human Rights" (2004) 5 Melb JIL 221, 237.

22 Baker $v$ Minister of Citizenship and Immigration [1999] 2 SCR 817. 
humanitarian and compassionate considerations pursuant to regulations made under section 114(2) of the Immigration Act 1985 ("Immigration Act").

The Canadian Supreme Court did not hold that a legitimate expectation with legal consequences had been created by Canada's ratification of UNCROC. ${ }^{23}$ However, a majority of the Court considered that Canada's ratification of UNCROC indicated "the importance of considering the interests of children" 24 when exercising the power under section $114(2)$ of the Immigration Act. ${ }^{25}$ The Court observed that: ${ }^{26}$

the values reflected in international human rights law may help inform the contextual approach to statutory interpretation and judicial review.

Tavita was cited in support of the proposition that: ${ }^{27}$

The important role of international human rights law as an aid to interpreting domestic law has also been emphasised in other common law countries.

The appeal was allowed.

By the time Tavita was decided, Cooke was clearly correct to say that relationship between international human rights norms and domestic law was "undergoing evolution". ${ }^{28}$ The evolution was occurring and continues to do so in New Zealand, Australia, and elsewhere. ${ }^{29}$ Cooke played an important part in the process that he described. Indeed, the developments in this area led Chief Justice Elias to remark (referring to the words of Sedley LJ) that "[n]ow, international human rights standards 'march with the common law'." 30

23 Ibid, 841 L'Heureux-Dubé J.

24 Ibid, 860 para 69 L'Heureux-Dubé J.

25 L'Heureux-Dubé J wrote the reasons of the majority. Cory and Iacobucci JJ, in the minority on this issue, concluded that international law which had not been implemented in domestic legislation could not affect statutory interpretation.

26 Baker, above n 22, 817, 861 para 70 L'Heureux-Dubé J.

27 Ibid. See also Mabo v Queensland (No 2) (1992) 175 CLR 1, 42.

28 Tavita, above n 17, 266 Cooke J.

29 See my earlier discussion of this phenomenon in Michael D Kirby "Lord Cooke and Fundamental Rights" in Rishworth, above n 1, 331, 346-348.

30 Sian Elias "Sovereignty in the 21st Century: Another Spin on the Merry-go-round" (2003) 14 PLR 148, 157, citing $R \vee$ Secretary of State for the Home Department; Ex parte McQuillan [1995] 4 All ER 400, 422 Sedley LJ (CA). 
Common law of the world: The insight that international and domestic law were becoming more interactive probably informed Cooke's view that a common law of the world was gradually developing. For him, it was at least a kind of international common law of civilised countries.

In a speech delivered on 17 December 1997, Cooke observed that his first address on this topic, delivered two years earlier, had been titled "The Dream of an International Common Law". He observed that a fortnight earlier, he had delivered a paper "called, more boldly, The Common Law of the World". ${ }^{31}$ He went on: ${ }^{32}$

So you will infer that I gained a little in confidence over the two years.

He continued:

The title of [the latter] lecture was avowedly proleptic. No one suggests that there is yet a common law of the world. It is many, many years ahead. But that it is ahead I am reasonably confident. In at least three main areas, one can see clear evidence of progress in that direction.

The three identified areas were: ${ }^{33}$

- [The] interaction between national jurisdictions in the use of precedents, a form of crossfertilisation;

- [T]he gradual development of what is called by some the new lex mercatoria, and is otherwise known by various descriptions such as general principles of international commercial law; and

- [T]he great one of human rights, encapsulated at the most general level in the Universal Declaration of Human Rights.

In a lecture delivered in October 2003, Cooke identified: ${ }^{34}$

[A] widespread movement towards a common law of the world in the fields of human rights and commercial law (eg Uncitral).

The idea of a common law of the world is a powerful, evocative one. Like Cooke, I also see a developing movement towards a greater recognition and reflection of universal human rights in

31 Robin B Cooke "The Judge in an Evolving Society" (1998) 28 VUWLR 467, 469. It appears that the paper entitled The Common Law of the World was not published although Cooke indicated that some of it was adapted and incorporated into the speech "Party Autonomy": see Robin B Cooke "Party Autonomy" (1999) 30 VUWLR 256, 268, footnote 18.

32 Cooke "The Judge in an Evolving Society", ibid, 469 (emphasis in original).

33 Ibid, 469, 470-471 and 471 respectively.

34 Robin B Cooke "The Road Ahead for the Common Law" (2004) 53 Int'l \& Comp LQ 273, 273. 
domestic law. As a judge, Cooke showed himself to be respectful of universal human rights and human dignity although he was careful not to promote these norms in a manner inconsistent with his judicial functions.

Those of us brought up in Commonwealth countries, formerly linked through the Privy Council to a rich source of comparative law materials, were aware all our professional lives of the value of comparative law stimuli for our analogical reasoning. What was new, and called to notice by Cooke, was the very large growth in the impact of treaty law, its increasing importance in resolving business disputes and the greater willingness to look beyond the familiar sources for relevant materials, namely the courts of the old British Dominions. Pervading it all, there was the steadily growing impact of international human rights law as an impetus to action and as a touchstone for our own legal advances.

\section{APPROACH TO JUDGING}

An activist judge?: Chief Justice Elias observes that Cooke did not see himself as a social engineer: ${ }^{35}$

Contrary to folklore, Lord Cooke believed that it is not the role of the judge to mould society.

In his article "The Myth of Sovereignty", Cooke explained his view as to why the courts were not sovereign. In so doing, he gave an insight into his thoughts about the proper role of the courts: ${ }^{36}$

Despite the quite widespread pejorative misuse of the term "activist", judges cannot initiate action and ... disclaim responsibility for decision-making in many spheres of the nation's life. Certainly the courts make common law, developing it usually by a gradual process of accretion and modification, sometimes, though, by giant strides. ... As regards legislation, however, the conventional judicial approach is confined to interpretation in the ordinary sense.

In discussing criticisms of his position (and that of like-minded judges) on fundamental common law rights, Cooke responded that: ${ }^{37}$

The number of decisions in which judges of the criticized school of thought have recognized that actual legislative or administrative intent should prevail is untold and huge.

Cooke was never in doubt that judges develop the law. In 1989, he wrote: ${ }^{38}$

35 Elias "Eulogy", above n 4, 325.

36 Robin B Cooke "The Myth of Sovereignty" (2005) 3 NZJPIL 39, 42-43. For a description of Cooke's opinion of the use of the term "judicial activist" see Philip A Joseph Constitutional and Administrative Law in New Zealand (2 ed, Brookers, Wellington, 2001) 756 [20.4.2].

37 Cooke "The Road Ahead for the Common Law", above n 34, 273, 278. 
In New Zealand there has been for some time a tendency to some judicial glasnost. ... It has become less common to pretend that questions can be solved by combining bits of existing knowledge or precedent...

There is now a more open acknowledgement that deciding a new point may not be primarily a process of deduction

Indeed, in the following year, he observed: ${ }^{39}$

Every judicial decision, to some extent, makes law, since cases cannot be decided by computer, but the great majority are not concerned with frontiers of legal development.

My agreement with this assessment of the judicial method is well known. ${ }^{40}$ In a recent article, I paid specific tribute to Cooke's impact upon our understanding of the judicial function. I explained how the "legal Reformation" which occurred "particularly in the latter part of the twentieth century" had dispelled the myth that judges do not make law. I observed that: ${ }^{41}$

Greater honesty and candour about judicial reasoning is the abiding legacy of the enlightenment that came with the legal Reformation.

I added that "[i]n New Zealand, [this development] is a great legacy of Sir Robin Cooke's time as President of the Court of Appeal".

Separation of powers: Cooke explained that what was central to the judicial function was not a denial of the notion that judges create law. Instead, he argued that impartiality in adjudication is central to the proper performance of that function: ${ }^{42}$

[U]nlike politicians whose concern is naturally with policy, judges have as their primary role impartiality. The two vocations are essentially different, despite from time to time an inevitable overlap in some grey areas.

The key role of impartiality did not mean that judges should shy away from cases before them, even if these cases were socially or politically controversial. In fact, for Cooke, impartiality

38 RB Cooke "Fairness" (1989) 19 VUWLR 421, 421-422.

39 Robin B Cooke "Dynamics of the Common Law" [1990] NZLJ 261, 262.

40 See, for example, Michael D Kirby "Judicial Activism: Power without Responsibility? No, Appropriate Activism Conforming to Duty" (2006) 30 Melb ULR 576; Michael D Kirby Judicial Activism: Authority, Principle and Policy in the Judicial Method (Sweet \& Maxwell, London, 2004) (Hamlyn Lectures).

41 Michael D Kirby "'Judicial Activism'?: A Riposte to the Counter-Reformation" (2005) 11 Otago L Rev 1, 14-15.

42 Cooke "The Myth of Sovereignty", above n 36, 41. On the great importance of integrity and impartiality in carrying out the judicial task, see Cooke "The Judge in an Evolving Society", above n 31, 468. 
demanded the resolution of difficult legal issues in cases with important political and social consequences: 43

There is not much point in accepting judicial office unless one tries to accept the unwelcome or disturbing, but crucially independent, responsibilities that go with it.

In the particular context of administrative law, he argued that: 44

judicial review is a demanding arena, as the Courts cannot shrink from rulings bearing on even the most socially divisive issues of the day - political, moral, economic. Here the judicial role is not to resolve the issues but to act as a check or to keep the ring, trying to ensure that those responsible for decisions in the community do so in accordance with law, fairly and reasonably.

Respect for human rights: Cooke's judicial decisions also demonstrate that approaching the judicial function with impartiality does not require a restrictive or overly verbalistic approach in interpreting the law regarding fundamental rights and freedoms. In discussing the Bloemfontein Statement's principle that "in democratic societies fundamental human rights and freedoms ... form part of the law", Cooke provided guidance regarding the interpretation of laws that touch upon human rights and freedoms: ${ }^{45}$

[I]n blending [fundamental human rights and freedoms] into the corpus of the law, Judges have to learn to rise above any black-letter technique, avoiding what Lord Wilberforce has famously labelled "the austerity of tabulated legalism". In Privy Council judgments often cited, the great British Judges Wilberforce and Diplock have recommended a generous approach to the interpretation or application of broad-textured human rights declarations. It is the generality and character of the declarations that makes this approach apt. Whether or not a given declaration is also entrenched in supreme law is beside the point.

The principle of fairness: Nor, for Cooke, did impartiality exclude considerations of fairness. His basic approach to judicial decision-making is revealed by his explanation that the process is not

43 Robin B Cooke "The Challenge of Treaty of Waitangi Jurisprudence" (1994) 2 Waikato LR 1, 6.

44 Robin B Cooke "The Struggle for Simplicity in Administrative Law" in Michael Taggart (ed) Judicial Review of Administrative Action in the 1980s: Problems and Prospects (Oxford University Press/Legal Research Foundation, Auckland, 1986) 1, 16-17.

45 Cooke "A Sketch from the Blue Train", above n 9, 12, citing Lord Wilberforce in Minister of Home Affairs $v$ Fisher [1980] AC 319, 328 (PC (Bermuda)). Lord Wilberforce told Cooke that he believed that the phrase was to be attributed to Benjamin Cardozo: Robin B Cooke "Practicalities of a Bill of Rights" in W K Hastings (ed) F S Dethridge Memorial Addresses 1977-1988 (Maritime Law Association of Australia and New Zealand, Auckland, 1989) 71, 78. 
simply one of deduction from existing legal principle but rather it involves "the search ... for the solution that seems fair and just after balancing all the relevant considerations." 46

The article from which this quotation is taken, simply titled "Fairness", is a highly instructive account of how "fairness" can and, at least in the law of New Zealand, ${ }^{47}$ does play a vital role in shaping the law. ${ }^{48}$

A fine example of Cooke's approach in this respect appears in his essay "The Struggle for Simplicity in Administrative Law". ${ }^{49}$ In that essay, he suggested an underlying principle for judicial review that has remained in my mind since I first read it because of the power of its simple exposition of the legal bedrock: ${ }^{50}$

It is submitted for your consideration that the substantive principles of judicial review are simply that the decision-maker must act in accordance with law, fairly and reasonably.

For Cooke, this was the very core of judicial review. In his opinion, the ambit of the more specific tools of administrative law did not need to be circumscribed. They could safely be left flexible and adaptive so as to serve the three bedrock principles that he named.

Demystifying law: Cooke's strong belief in simplifying and demystifying legal discourse was also evident in that essay. Thus, he took the common use of administrative law expressions to task: ${ }^{51}$

Serving a useful enough purpose in their day, they are seen in time to distract attention from the true question: terms like quasi-judicial, nullity, jurisdiction, jurisdictional fact, the face of the record. ...

Obscure concepts hinder progress. So to attempt more direct and more candid formulations of principle has more than semantic purpose.

46 Cooke "Fairness", above n 38, 422.

47 Cooke suggested that, in 1987, the High Court of Australia followed a similar approach. He cited extracts from the joint reasons of Mason CJ and Wilson and Deane JJ in Baumgartner v Baumgartner (1987) 164 CLR 137 as an example.

48 For a discussion of Cooke's explicit use of "fairness" in judicial decisions, see Spiller New Zealand Court of Appeal, above n 2, 121, and generally at 131-133.

49 Cooke "The Struggle for Simplicity in Administrative Law", above n 44. The title for the Festschrift for Cooke, The Struggle for Simplicity in the Law: Essays for Lord Cooke of Thorndon, was no doubt intended to allude to that essay's title.

50 Ibid, 5. For a more comprehensive overview of Cooke's approach, see Joseph, above n 36, 777 [20.9].

51 Cooke "The Struggle for Simplicity in Administrative Law", above n 44, 5. 
The same approach is also evident in his strong preference for the use of "reasonable" and "unreasonable" in characterising decisions subject to review instead of "[v]ituperative epithets like perverse, frivolous [and] foolish" or "distracting circumlocutions" such as "'[s]o unreasonable that no reasonable authority could come to it"'. ${ }^{52}$ We see at work here a legal mind of the highest order, sharpened by decades of daily experience participating with others in courts of great ability. His was the kind of mind that was at home and comfortable in the winding valleys and byroads of law's countless problems. But, it could also soar to lofty heights and look down and survey everything below - identifying the entire terrain and showing ways to cut through obstructions once the topography of law was more clearly perceived.

I agree wholeheartedly with Cooke's sentiments in this respect. This is a topic about which I have written. ${ }^{53}$ The movement towards the simplification of legal language has made progress and I trust that the progress will continue and accelerate. Yet even more important than simple language are simple concepts of law. The common law system, and common law techniques, can sometimes be resistant to over-arching concepts. We solve immediate problems without always taking the trouble to identify our basic concepts or without even being sure that any exist. Cooke was one of those rare judicial birds who struggled to see and to describe the concepts. This was because of the power of his mind combined with the length and variety of his high judicial offices.

Personal qualities: It is important to mention the personal qualities that Cooke demonstrated as a judge. While on the bench, he certainly displayed courage in fulfilling the "unwelcome or disturbing ... responsibilities" that judicial office required him to bear. Professor Spiller was correct to discern that Cooke "possessed a deep-rooted humanity". ${ }^{54}$ He was also enormously industrious, with unflagging energy, as evidenced both by his judicial output and his extrajudicial contributions. He was a true intellectual. However his creative capacity was safely tethered to concrete realities by decades of day to day decision-making as a judge resolving highly practical and often mundane legal problems.

52 Ibid, 14-15; see also 16. On Cooke's use of concise and simple statements of the law, see further Peter Spiller "A Commonwealth Judge at Work: Lord Cooke in the House of Lords and Privy Council" (2003) 3 OUCLJ 29, 34-35.

53 See, for example, my review of Joseph Kimble Lifting the Fog of Legalese: Essays on Plain Language (Carolina Academic Press, Durham (NC), 2006) in (2006) 80 ALJ 623.

54 Spiller New Zealand Court of Appeal, above n 2, 121, and generally 121-122. 


\section{A DISTINCTIVE NEW ZEALAND JURISPRUDENCE}

Evolution to distinctiveness: Before the 1960s, with very few exceptions, New Zealand case law closely followed English legal principles. Chief Justice Elias has observed that: 55

In 1956, on his return from Cambridge, [Cooke] criticised the New Zealand judiciary for its

"unquestioning compliance" with English case law.

During Cooke's time as a judicial officer in New Zealand, the pace of the evolution of a New Zealand jurisprudence accelerated greatly. This movement, to which he was one - but by no means the only - contributor, resulted in the creation of a distinctive New Zealand jurisprudence. ${ }^{56}$ In delivering The Robin Cooke Lecture 2003, Chief Justice Elias observed that "[n]o one has contributed more than Lord Cooke of Thorndon" to the development in New Zealand of "a home in thought for New Zealand law". ${ }^{57}$ In a sense, the legal environment that welcomed and encouraged fresh opinions was also one that recognised the merit of the young Cooke's criticism of 1956. In Australia, a similar movement eventually emerged. Strangely, it seems to have done so mainly as an outcome of the severance of the Privy Council links, finally achieved in $1986 .{ }^{58}$ Although New Zealand retained those links for a longer time - or perhaps because of this - the asserted legal independence emerged earlier and seemed at first, if anything, more assertive.

Cooke was first appointed a judge in 1972. In 1976, he was elevated to the New Zealand Court of Appeal. In 1984, he reported that: ${ }^{59}$

A low-key, unspectacular, but quite deliberate, movement has been taking place in New Zealand case law in recent years. In various directions we have been cautiously evolving a New Zealand common law.

This was said by Cooke to "perhaps suggest that the New Zealand judicial system is now more attuned to [a] wider role than in the eras of Colonial and then Dominion status." 60 By 1988, he was even more emphatic about the distinctiveness of New Zealand law: 61

55 Elias "Eulogy" [2006], above n 4, 325, citing Robin B Cooke "The Supreme Tribunal of the British Commonwealth?" (1956) 32 NZLJ 233, 235.

56 For some discussion of that distinctive jurisprudence, see Spiller New Zealand Court of Appeal, above n 2 , chapter 17, especially 394-409.

57 Sian Elias "Something Old, Something New: Constitutional Stirrings and the Supreme Court" (2004) 2 NZJPIL 121, 137.

58 Australia Acts 1986 (Cth and UK), s 11.

59 Cooke "Practicalities of a Bill of Rights, above n 45, 71, 83.

60 Ibid, 83. 
The stage has now been reached in which in virtually every major field of law New Zealand law is radically, or at least very considerably, different from English law.

In part, this evolution was the product of a greater willingness of New Zealand judges to consider non-English jurisprudence. In 1996, delivering his contribution to the Hamlyn lecture series, Cooke observed that: ${ }^{62}$

In the New Zealand Court of Appeal few significant cases would pass without consideration of at least Australian and Canadian case law, as well as United Kingdom decisions. United States cases and texts, including of course the Restatement, are consulted rather less frequently but almost invariably on novel problems in such fields as tort, contract, evidence and the Bill of Rights.

Abiding English influence: From this exposition it is clear that, despite the evolution of a uniquely New Zealand law, English law remained (and probably still remains) the most important influence upon the development of New Zealand law. Chief Justice Elias has emphasised that Cooke was a supporter of the constitutional monarchy who: ${ }^{63}$

... believed that in the rightful development of a New Zealand national identity "we need not throw away the privilege of a link to an ancient and much larger society as well".

Internationalism and comparativism: Cooke contributed not only to making New Zealand courts consider relevant law other than English law. He also performed the much more remarkable feat of leading English courts to consider and use non-English law in a way that had not previously been essayed. Lord Steyn has observed: ${ }^{64}$

[He] helped in making the House of Lords more internationalist. There was an earlier era when lip service was paid to comparative law and English solutions were found to be best. Lord Cooke helped to change that, and now there is a greater debate between the House of Lords and other superior Courts. Lord Cooke understood that comparative law involved assessing different feasible solutions in their cultural contexts and refining solutions.

In this approach to the decisions of foreign courts, Cooke's views resonate strongly with my own approach. They point the way in which Australian jurisprudence too should develop - drawing, as in the past, on the traditional influences of English law, but also reaching out for legal wisdom in other

61 Cooke "Fundamentals" [1988] NZLJ 158, 158.

62 R B Cooke Turning Points of the Common Law (Sweet \& Maxwell, London, 1997) 3.

63 Elias "Eulogy", above n 4, 325.

64 Spiller "Lord Cooke of Thorndon: The New Zealand Dimension", above n 3, 66 providing transcript of a part of an interview with Lord Steyn at the House of Lords on 11 June 2002. 
common law jurisdictions including the United States, Canada, Ireland, South Africa, India, Hong Kong and, of course, New Zealand.

The new Supreme Court: Although described by Chief Justice Elias as "a relatively late convert to the creation of a local final appellate court", ${ }^{65}$ Cooke eventually became an advocate for the abolition of appeals from New Zealand to the Privy Council. ${ }^{66}$ Given his stature in New Zealand on legal matters, I do not doubt that his support, when it came, was an important contributing factor towards the final decision. In a sense, he helped develop a New Zealand jurisprudence that was freed from the binding force of English law whilst continuing to draw on that rich heritage as appropriate - and making the heritage even richer by the belated embrace of the English judges of a willingness to invoke Commonwealth jurisprudence in developing their own.

The establishment of the Supreme Court of New Zealand is, as he recognised, a great turning point in the development of the law of New Zealand. ${ }^{67}$ It is not entirely unconnected that, in 2008 , the United Kingdom will inaugurate its own Supreme Court, divorced from the House of Lords, installed in a new building across Parliament Square, but taking with the books and personnel many of the precious ideas of comparative and human rights law advocated by Cooke during his service on the Judicial Committee of the Privy Council and in the House of Lords in its last decade.

An apparent contradiction?: One might ask if Cooke's view that a common law of the world is evolving is inconsistent with his energetic contribution to the development of a distinctly New Zealand jurisprudence? For example, it might be thought that the development of a common law of the world would be hastened by New Zealand's continued adherence to English precedent, as a kind of transnational jurisprudence operating on the exact opposite side of the world and not by stimulating yet another distinct and separate municipal legal system.

The resolution of this apparent contradiction lies in the contribution that Cooke saw that New Zealand could make to the international common law. In 1993, he wrote that: 68

65 Sian Elias "Something Old, Something New: Constitutional Stirrings and the Supreme Court" (2004) 2 NZJPIL 121, 122. Cooke first revealed his change of view on this subject in an address to the New Zealand Law Conference in October 1987. See Robin B Cooke "The New Zealand National Legal Identity" (1987) 3 Cant LR 171, 180-183.

66 See, for example, Cooke "A Sketch from the Blue Train", above n 9, 14.

67 I use "turning point" in reference to Cooke's Hamlyn Lectures, "Turnings Points of the Common Law", which examined four key cases that developed the common law. Cooke's judicial service likewise marks an important turning point in the common law of New Zealand and New Zealand law generally.

68 Cooke "A Sketch from the Blue Train", above n 9, 14. 
All democratic nations contribute to the universal law, slowly but inevitably evolving, as to freedom of speech and other basic human rights.

That opinion was written before his first essay appeared examining the concept of a common law of the world. It reveals an earlier explanation of his idea. It provides an important insight into his vision for the common law of the world. It is a system of laws that would not be imposed by one national jurisdiction upon others but would emerge over time from the development of the law in different jurisdictions across the world and by the cross-fertilisation of these developments as between the courts of many nations engaged in a free dialogue. In his Hamlyn lectures, Cooke observed: 69

[T] he shrinking of the jurisdiction of the Privy Council can be said to have in truth promoted the development of the common law. Seen now from a wider perspective, contributions from the various jurisdictions can be weighed according to their intrinsic merits rather than by mentally allotting them places in a hierarchy.

If there is one clear source to stimulate the development of a common law of the world, it must surely be that great body of international law that developed after the Second World War concerned with human rights and also, with increasing power in recent decades, concerned with international and regional trade and commerce. Cooke's vision of a common law of the world was built upon a humanistic belief that there will ultimately be universal recognition of fundamental legal principles, including those relating to human rights and basic freedoms.

Some sceptical souls will dismiss these ideas as dreams of elderly judges dreaming of Nirvana on this Earth before they go elsewhere where they might (or might not) find such bliss. I accept that there is a large amount of idealism in Cooke's vision. But the very notions of justice, fairness and due process are statements of ideals - concepts that we strive to attain in day to day legal practice. Likewise with human rights. There are ideals that modern lawyers should never be ashamed of or embarrassed about.

Contribution to a noble ideal: Cooke's vision for the law was of a future in which domestic legal systems develop law that is distinctive but also grounded in a core of universal principles. These legal systems would provide solutions appropriate to local circumstances, history and culture. However, they would also provide universal recognition for basic or fundamental human rights. Gradually, step by patient step, many nations and their legal systems are moving towards the recognition of fundamental human rights and freedoms in their domestic law. If this is what Cooke's prediction for a common law of the world involved, I hope that it will be realised. Contemporary 
lawyers and judges in countries such as New Zealand and Australia are privileged to play a part in advancing this noble ideal.

\section{A PACIFIC CHARTER?}

Human rights in the Pacific: I now want to attempt one of those leaps of the imagination that Cooke quite often made. I hope that it can be accomplished with the same apparently effortless skill. Cooke not only wrote as a scholar and judge about global human rights. He also did practical things from the bench and the lectern to give his thoughts a concrete shape. As well, he dreamed about the future of the discipline of law. And he shared his dreams with us to stimulate, focus and advance our own thinking.

One practical way in which we might seek to realise Cooke's goal of a common law of the world, incorporating fundamental human rights, would be to create a bill or charter of rights for the Pacific region - our immediate neighbourhood. Such a regional charter of rights might cover New Zealand, Australia, Papua New Guinea and the Pacific Island states and self-governing entities. A Pacific Charter of Rights would certainly be consistent with the vision that Cooke held for the law at once principled, founded in rules, upheld by independent courts and other bodies and based on universal rules given effect in the distinctive environment of one's own nation.

Regional charters of rights are already established for Europe, ${ }^{70}$ the Americas ${ }^{71}$ and Africa. ${ }^{72}$ All of these regions have courts and/or commissions to give effect to the fundamental rights that they espouse and to decide individual claims. Only Asia and the Pacific now stand outside this global network of institutions for human rights protection. If the attainment of a human rights charter and institution for Asia seems unattainable in the immediate future, the same need not be so for the Pacific states which share more intensive links of history, similar ideals of governance, a largely common legal tradition and many shared economic interests. This is therefore an idea that we should re-examine. In my view, it is far from being unattainable.

Cooke had several important links with the Pacific Island nations. During his judicial career, he participated in appellate courts in Fiji, Samoa, the Cook Islands and Kiribati. His decisions in New Zealand were highly influential throughout the Pacific, in part because many of the future legal

70 Convention for the Protection of Human Rights and Fundamental Freedoms (4 November 1950) 213 UNTS 222.

71 American Convention on Human Rights (22 November 1969)1144 UNTS 123.

72 African Charter on Human and Peoples' Rights (27 June 1981) 1520 UNTS 217. 
leaders of the Pacific came to New Zealand for their legal training. He was supportive of the assistance provided by New Zealand judges to Pacific nations. In December 2001 he said: ${ }^{73}$

Traditionally the New Zealand judiciary provides help in the Pacific region; and this should be catered

for wherever needed.

The Australian judiciary has also played a useful role in contributing to the work of courts in the Pacific region. Before my appointment to the High Court of Australia, between 1995 and 1996 it was my privilege to serve as President of the Court of Appeal of Solomon Islands. That service taught me the many things we held in common. I presided in hearings with judges from New Zealand, Australia, Papua New Guinea and Solomon Islands. The experience opened my mind to many practical possibilities of cooperation.

Content of a Charter: Obviously, a Pacific Charter would be strongly influenced by the rights recognised by international declarations and conventions achieved under the auspices of the United Nations. Perhaps the strongest influence would derive from the Universal Declaration of Human Rights which Cooke once declared to be "the most important document in legal history". ${ }^{74}$ That Declaration, with its clear and simple text, served as a precursor to the development of the International Covenant on Civil and Political Rights and the International Covenant on Economic, Social and Cultural Rights. It derived its great moral force from the sacrifice of those who had fought against tyranny in the Second World War and by the revelations of genocide and unparalleled suffering that became evident in the aftermath of that great conflict.

One theme of a Pacific Charter would be the protection of minority rights. Cooke identified "a respect for minority interests" as one of the principal constitutional rules "underlying western-style democracies". ${ }^{75}$ While acknowledging the difficulty of defining the governing notion precisely, he declared that: ${ }^{76}$

this does not mean that the task has to be given up as hopeless. The general similarity in content of formal human rights declarations and instruments, broadly inspired in turn by the Universal Declaration of Human Rights, represents progress towards a solution.

73 Robin B Cooke Final Courts of Appeal: Some Comparisons (Occasional Paper No 7, Victoria University of Wellington Faculty of Law, Wellington, 2001) available at www.vuw.ac.nz (accessed 10 May 2007).

74 See Elias "Eulogy", above n 4, 325.

75 Robin B Cooke "Foreword" in Michael D Kirby Through the World's Eye (Federation Press, Leichhardt (NSW), 2000) xi, xvii.

76 Ibid, xvii (footnote omitted). 
There would also be a need to ensure that the recognition of basic rights applicable to all Pacific countries would be culturally appropriate. If it were suspected that such rights were being imposed on varied societies by developed nations in their midst, without consultation, the idea would never gain the necessary support of the diverse peoples and nations of the Pacific.

On the other hand, it would be important not to allow concerns about cultural relativism to prevent the recognition of fundamental and region-wide rights. Valuable guidance could be derived from a return to the work of LAWASIA in the late 1980s and early 1990s on a draft of a Pacific Charter of Human Rights. ${ }^{77}$ That draft Charter recognised not only individual human rights but also important rights of peoples and the duties of governments and individuals. The emphasis on duties and responsibilities would possibly help to ensure that a Pacific Charter would not interfere in an unacceptable way with the notions of community and, in particular, the sense of the duty to a community, which exists in virtually all Pacific Island cultures.

A Court or Commission?: To ensure that such a Pacific Charter secured greater support and spread its influence throughout the region, it would be essential to establish a specialised regional human rights commission and/or court for the Pacific region.

In Europe, the European Court of Human Rights plays a most beneficial role of great importance. Its jurisdiction extends from Galway in Ireland, in the West, to Vladivostok in the Russian Federation, in the East. Arguably, this is the most influential court in the world today. In the Americas, there is the Inter-American Court of Human Rights and the Inter-American Commission on Human Rights. In Africa, there is the African Court on Human and Peoples' Rights and the African Commission on Human and Peoples' Rights. All of these institutions fulfil vital functions in their respective regions. In varying degrees, they have proved effective in furthering the recognition and defence of fundamental human rights in their respective regions. Such a court or commission would be a great asset in the Pacific region. As citizens of countries in the Pacific, we are entitled to ask whether the state of human rights and fundamental freedoms is so perfect in the nations of the Pacific region that, unlike our counterparts in Europe, the Americas and Africa we have no need for the checks, protection and stimulus that such commissions and courts can provide.

In my opinion, the work of LAWASIA provides a most useful reference point for reviving discussion of the appropriate norms and institutions for Pacific nations. The draft Charter prepared by LAWASIA envisaged the creation of a Pacific Human Rights Commission in the first instance. Such a Commission would have the function not only of investigating individual cases of alleged human rights infringements but also of conducting broader studies of human rights issues, and of

77 See the draft Charter in the Report on a proposed Pacific Charter of Human Rights prepared under the auspices of LAWASIA, May 1989, which is published in (1992) 22 VUWLR 99, 145. 
educating and developing awareness of human rights issues throughout the region. Such a multifaceted strategy for the protection of human rights would certainly be timely in our region.

Recent events in Pacific countries point to the special need for such an institution. In Europe, the Americas and Africa the process of implementing regional human rights instruments began with the work of a low key investigative Commission. Initially, this could be viewed as less threatening to governments unused to external stimuli for, or criticism of, their human rights records. In other regions courts have developed their jurisdictions later in time. There is every reason why a Pacific Charter initiative should follow a similar course.

Prospects of a Charter: A Charter of Rights for the Pacific region is not yet a subject widely discussed by political leaders. It will depend upon lawyers, judges and civil society organisations to place the issue on the regional agenda. All this was done in other regions of the world it is clearly possible and achieveable in the Pacific where the institutional, linguistic and economic commonalities are greater and the impediments appear less strident. Despite the present lack of a political momentum towards such an institution, it is remarkable how quickly such a momentum can build up. To that end, it is worth assessing whether the necessary conditions for such a Pacific Charter are in place.

One important factor that, in my view, gives cause for hope is the widespread recognition of basic human rights in the national, post-independence constitutions of Pacific Island nations. ${ }^{78}$ In 1991, it was possible for Professor Patricia Hyndman to write: ${ }^{79}$

All of the independent Pacific Island States have bills of rights incorporated within their Constitutions.

The Pacific Constitutions and the bills of rights incorporated in them are all supreme law.

Even though the rights that appear in the constitutional documents of the Pacific nations are not justiciable in all of these countries, the formal recognition of basically similar fundamental rights is a significant step in the direction of seeking to identify a core of agreed rights around which a Pacific Charter could cluster.

Although New Zealand has adopted the New Zealand Bill of Rights Act 1990, Australia still lacks a general, national charter of rights. In this respect, Australia lags behind developments that have occurred in virtually all other Western countries. Of course, Australia has many statutes

78 Tonga is the only Pacific nation that was not colonised but its Constitution has contained basic rights since its adoption in 1875: see Patricia Hyndman The Protection of Human Rights in the Pacific Region (Human Rights Unit, Commonwealth Secretariat, London, 1991) 6.

79 Ibid, 6 (footnote omitted). 
prohibiting specific forms of discrimination. ${ }^{80}$ Even so, Australia still has some way to go in addressing forms of discrimination not presently covered by universally applicable statute law, such as discrimination based upon sexual orientation. Despite the lack of a national charter of rights in Australia some progress has recently been made towards a more comprehensive protection of human rights in the sub-national polities. I refer to the enactment of legislative charters of rights in Victoria $^{81}$ and the Australian Capital Territory. ${ }^{82}$ The subject is now under consideration in Western Australia.

The time will come, probably before long, when Australia will adopt a charter of rights, initially in a statutory form and later, perhaps, as an amendment to the Constitution. The momentum that has occurred on this subject in Australia in recent years may reflect a similar mood amongst many Pacific states and an appreciation that our part of the world should not be cut off from the developments that have already occurred in other regions and that provide an example and stimulus to us.

A regional necessity: The absence of a human rights charter and commission for the Pacific region leaves a significant void in the protection of human rights for citizens of the nations of the Pacific. As a matter of principle, it is difficult, or impossible, to justify the absence of a regional Charter and institution available to us, serving the purposes fulfilled by the charters, courts and other bodies operating in equivalent settings for the people of Europe, the Americas and Africa.

The institutional void has not been filled by the adoption in the Pacific states of the most important human rights treaties and their incorporation in domestic law and enforcement within the region. Indeed, in mid-2007, of those states and self-governing entities in the Pacific, Australia and New Zealand are the only nation states that have ratified the International Covenant on Civil and Political Rights, although Nauru is a signatory. ${ }^{83}$ With respect to the ratification of the International Covenant on Social, Economic and Cultural Rights, only Australia, New Zealand and the Solomon Islands have done so. This means that the majority of states and independent entities in the Pacific do not submit to the jurisdiction of the treaty bodies that oversee adherence to the principles

80 For example Racial Discrimination Act 1975 (Cth), Sex Discrimination Act 1984 (Cth), Disability Discrimination Act 1992 (Cth), Age Discrimination Act 2004 (Cth)

81 Charter of Human Rights and Responsibilities Act 2006 (Vic).

82 Human Rights Act 2004 (ACT).

83 See International Covenant on Civil and Political Rights New York, 16 December 1966 available at www.ohchr.org (accessed 18 May 2007). 
enshrined in those treaties. ${ }^{84}$ Putting it bluntly, this is a lamentable state of affairs. The moves for a Pacific Commission on Human Rights would therefore serve both as a national and transnational stimulus to bring Pacific nations up to the mark in recognising and protecting the kind of universal human rights that all civilised nations should observe.

The past decade has seen a significant growth in the number of national human rights institutions established in the Asian region. According to the Australian agency for international aid ("AusAID"), ${ }^{85}$ in 1996, the Asia Pacific region had only four national human rights institutions accredited according to international standards. ${ }^{86}$ By mid-2007, there are 17 such bodies. The level of co-operation between these institutions, under the auspices of the Asia-Pacific Forum of National Human Rights Institutions, is to be welcomed. Brian Burdekin, an eminent authority in this field, has written that the Asia-Pacific Forum is, in this respect, "the most effective such association in any region". ${ }^{87}$ This is the more remarkable because of the absence of an Asian regional human rights body or court, the disparity of laws and cultures in Asia and the Pacific and the presence of some nations ostensibly hostile to the principles of universal human rights.

Nevertheless, these admirable developments have largely taken place in Asia, not the Pacific. In the Pacific region, only New Zealand, Australia and Fiji possess a national human rights institution. In 2007, the Fijian Commission has obviously been affected by yet another military coup against civilian government and constitutionalism in the Fiji Islands. This leaves a great number of states and self-governing entities in the Pacific without either a national or a regional human rights institution. The lack of international treaty body supervision in combination with the absence of a national and transational human rights institution in most countries means that a serious institutional void exists in human rights supervision, monitoring and protection in Pacific states.

To some extent, the small populations of some of the states and self-governing entities in the Pacific help to explain why, until now, it has proved difficult for each jurisdiction to establish and maintain its own national human rights body. A perfect opportunity is therefore presented for a regional body to pool collective resources and the wisdom of the people of the Pacific towards a greater recognition and protection of human rights. A human rights commission for the Pacific

84 I applaud the ongoing efforts towards ratification of the principal international human rights treaties, for example at the Commonwealth Pacific Regional Workshop on the Ratification of International Human Rights Instruments under the Pacific Plan held at Port Moresby on 28-30 March 2007.

AusAID Overseas Aid www.ausaid.gov.au (accessed 18 May 2007).

86 These standards are set out in the "Principles Relating to the Status of National Institutions" (the "Paris Principles", available at www.ohchr.org (accessed 17 September 2007).

87 Brian Burdekin National Human Rights Institutions in the Asia-Pacific Region (Martinus Nijhoff, Leiden, 2007) 120. 
would have the advantage of fulfilling the role of a region-wide institution, likely to be more aware of local customs and traditions than one based in Geneva, New York or as part of an Asian initiative. In the matter of community values, the Pacific states are often distinctive. A Pacific approach to human rights is therefore a timely initiative that could fulfil at once regional and national needs.

Avoiding the backwater: I have addressed what I regard as an important aim for the future of Pacific nations and peoples. I recognise and welcome the efforts that are being made in the Pacific states towards greater recognition and protection of human rights by intergovernmental organisations such as the Commonwealth Secretariat and the Pacific Islands Forum Secretariat, by national governments, by international organisations such as the United Nations Development Program, and by non-governmental organisations. However, it remains important to look to the future and to aim to secure further, and particularly institutional, achievements.

In other regional protections for human rights, the world has witnessed remarkable developments in the past thirty or forty years. Yet, so far, we have not been able to secure a comparable instrument or institution in the Pacific region. ${ }^{88}$ The time has come to do something about these defaults.

A Pacific Charter would provide an important practical and intellectual stimulus for the recognition and protection of the basic human rights of people living in the Pacific. It might also help to strengthen, in appropriate and mutually respectful ways, the important historical, cultural, political and legal ties between New Zealand, Australia and the nations of the Pacific Islands. Such a development would be a giant step for humanity towards a common law of human rights for the world. It is the type of development that, I believe, Cooke, were he still alive, would advocate and propagate.

For a decade I served with him when we were both Commissioners of the International Commission of Jurists. In that body the focus of attention was always on upholding the rule of law, safeguarding fundamental human rights and pushing forward the new frontiers which these goals present for humanity. A neglected new frontier for universal human rights is the Pacific. So distant from the great population and economic centres of the world (and the sites of major conflicts) the Pacific region tends to be neglected by the rest of the world. In this sense, it is a kind of intellectual and legal backwater. As a result, some observers mistake the appellation of "Pacific" as an assurance that ours is a region of universal peace, tranquillity and justice. While progress has been made, much remains to be achieved. The institutional arrangements for protecting fundamental human rights and upholding the international law of human rights in the Pacific states leaves much

88 For an overview of recent developments in the Asia-Pacific, see David K Malcolm "Development of human rights throughout the Asia-Pacific region" (2006) 80 ALJ 178. 
to be desired. As an essential attribute of good governance in the region, normative and institutional progress for the protection of human rights is needed. The way forward is clear enough. What is required is the will, the means and the governmental and popular commitment to this noble ideal.

\section{THE ACHIEVEMENT AND THE DREAM}

Cooke believed in the ability of lawyers and the judiciary to make a "worthwhile contribution ... towards the evolution of more just national and international societies." 89 During his lifetime, he certainly helped that evolution along in notable ways. He did so in New Zealand. He did so internationally and specifically in the Pacific region.

So soon after Cooke's death, we are not able fully to evaluate his legacy. This is because it is not yet fully realised. His intellectual and institutional contributions continue to influence developments today. They will do so well into the future until the time comes when his is but another famous name in the legal lexicon of our tradition. Those who quote his words will not, like us, have known his sharp eyes, his quizzical look, his shy laughter and his searing intelligence. We who knew him can see that his contribution has been enormous. Through his very substantial role in creating a distinctive New Zealand jurisprudence. Through his demand that law be expressed as simply as possible. Through his insistence that the law be fair and just for ordinary people. Through his promotion of universal human rights. Through his fearless approach to the judicial task. It is his commitment to universal human rights and the rule of law and his dream of an international common law that oblige us to consider our own duty to do more for these causes in the world, and especially in the Pacific, our region.

The Pacific will be the region of the twenty-first century. No longer neglected as a backwater for human rights observance and protection, it should become a new focus and an example for others of what can be achieved pacifically in multiracial and diverse societies in assuring respect for the fundamental dignity of all peoples and protecting their inalienable rights to justice. Robin Cooke showed the way. But will we follow?

89 Cooke "A Sketch from the Blue Train", above n 9, 17. 